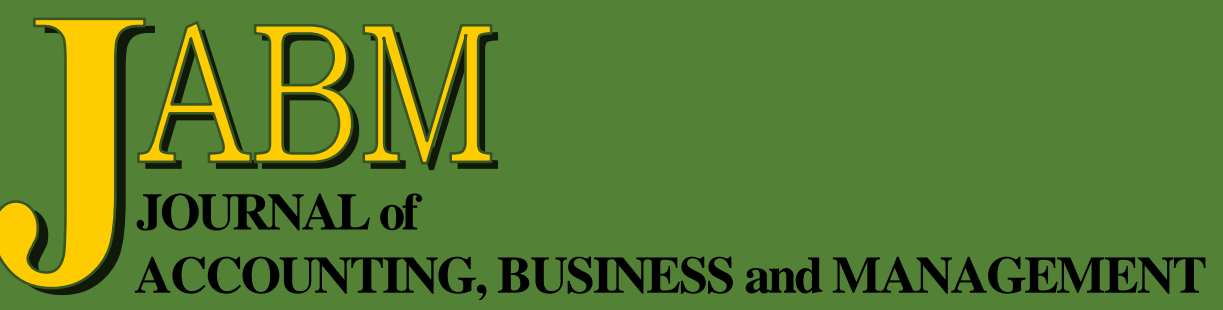

An Analysis of Management Accounting System Development from the Structuration Theory Viewpoint

Anthony Moung Yin Chan, Paul Lo and Kong Ng

Impact of Total Asset Turnover Ratios on Equity Returns: Dynamic Panel Data Analyses

Jeanne-Claire Patin, Matiur Rahman and Muhammad Mustafa

The Impact of Audit Committees on US Nonprofit Organizations'

Governance

Husam Abu-Khadra

Implicit Taxes Amid Race to the Bottom in a Global Tax Game

Igor Semenenko, Junwook Yoo and Parporn Akathaporn

The Adoption of Financial Accounting Standards for Small Medium Enterprises by Muslim Entrepreneurs

Muslichah, Sunarto, Anang Amir Kusnanto, Sri Indrawati and Hariyanto

The Impact of E-Procurement Systems in the Biomedical Industry

A. Seetharaman, Nitin Patwa, Simon Lai Koek Wai and Ahammed Shamir

After-Tax Discounting: A Research Edge

Hongtao Guo

Rules-Based Accounting Standards and SEC Enforcement

Devon Baranek 


\title{
The Impact of E-Procurement Systems in the Biomedical Industry
}

\author{
A. Seetharaman* \\ Nitin Patwa \\ Simon Lai Koek Wai \\ Ahammed Shamir $\$$
}

\begin{abstract}
The evolution of the Internet has revolutionised the sourcing and procurement processes in organisations in every industry. The focus of this paper is to analyse the perception of business users on the factors which impact the usage of eprocurement systems in the biomedical industry. There are four factors identified in this research: i.e. control and compliance, cost savings, process automation, and improvements and transparency. The benefit of achieving process automation is the first biggest factor, followed by the need for control and compliance, and transparency, being the second and third factors respectively. The fourth factor, cost savings, is ignored because the users perceived that cost savings will not be realised in the short term, and the returns from the investment could be a couple of years after the eprocurement system has been fully operational. The research also concludes that the ability to perform business analytics and to strengthen the supply chain are the most important factors in measuring the success in the adoption of e-procurement systems.
\end{abstract}

Keywords: electronic procurement, supply chain management, process automation, control and compliance, cost savings, transparency.

\section{INTRODUCTION}

Electronic procurement (e-procurement) is used as a means to reduce operational costs, enable volume purchase, allow a wider choice of buyers and sellers, improve delivery lead time, eliminate manual order taking and reduce paperwork and administrative costs (Doug \& Singh, 2001; Hsiao \& Teo, 2005). The Internet can act as an electronic marketplace, linking up buyers and sellers (Carabello, 2001). More than a dozen of e-procurement solution vendors like Ariba, Bravo Solution and Coupa (Adams et al., 2013) have emerged, and some of these vendors are offering their purchasing and expense-management platform on a software-as-a-service (SaaS) model.

E-procurement has become one of the key e-business strategies in many companies that have reaped enormous benefits by implementing e-procurement (Kulp et al., 2006). Companies which introduced e-procurement have achieved significant cost savings by as much as 8 to $15 \%$ (Tai et al., 2010), resulting in savings on transactional

\footnotetext{
* Dean-Academic Affairs. S P Jain School of Global Management Singapore. E-mail: seetha. raman@spjain.org.

† Associate Professor. Director Simulations-Dubai, S P Jain School of Global Management, Dubai. Block 5, Dubai International Academic City, P O Box 502345, UAE. Phone: +971 4 5616749. E-mail: nitin.patwa@spjain.org. Web page: www.spjain.org.

¥ Research Scholar. S P Jain School of Global Management, Dubai.

$\checkmark$ Senior Academic Manager (Global Logistics \& Supply Chain Management). S P Jain School of Global Management, Dubai. E-mail : ahammed.shamir@spjain.org.
} 
costs, more competitive sourcing and improved coordination within the organisation (Yen \& Ng, 2003; Agi et al., 2005; and Craighead et al., 2006).

Research on the impact of e-procurement has been conducted for many industries including construction, healthcare and the public sector. However, there has been little research conducted on the biomedical industry. Thus, the objective of this study is to examine the impact of e-procurement systems on the biomedical industry. A model comprising a set of factors impacting the adoption and the usage of eprocurement systems in the biomedical industry is presented and empirically tested.

In 2010 , US $\$ 100$ billion was invested in research and development (R \& D) processes for drug development, including drug discovery, pre-clinical investments and clinical phases as reported by international enterprise (IE) Singapore in 2011. A majority of these investments were directed to the outsourced biomedical R \& D markets in Asia as well as Eastern Europe. It also reported that the global contract research market was valued at US\$ 25 billion in 2010, and was expected to grow at a compound annual growth rate (CAGR) of 15\% from 2010to 2015. Biomedical sciences (BMS) accounts for $6 \%$ of Singapore's GDP and BMS manufacturing output to date is more than US\$23 billion. The economic development board (EDB) of Singapore also announced that US\$3.7 billion was being utilised to upgrade infrastructure, improve the biomedical $\mathrm{R} \& \mathrm{D}$ sector and to carry through the research into commercial products. As a result, the government has succeeded in attracting the world's top biomedical sciences companies like GlaxoSmithKline and Novartis to set up their $\mathrm{R} \& \mathrm{D}$ home base in Singapore.

In the public sector, the key biomedical R \& $\mathrm{D}$ infrastructures supporting the country's BMS initiatives include Biopolis, overseen by Singapore's A-STAR (agency for science, technology and research), the academic campuses of National University of Singapore (NUS) and Nanyang Technological University Singapore (NTU), as well as clinical research in the hospitals under the sing health and national healthcare group (NHG). The establishment of the biomedical sciences industry partnership office (BMS IPO) in 2011 was another effort by the Singapore government to facilitate further the translation of basic science into viable commercial entities, services or products via public-private partnership. In the private sector, as a result of the government's efforts to attract foreign investments, Singapore's stable economy, highly skilled labour force and friendly regulatory and physical infrastructure, many prominent biopharmaceutical companies like Lonza, MSD and Pfizer have opted for Singapore as their global manufacturing site.

As outlay in R\&D investments increases, many of the biomedical and biopharmaceutical industries are under enormous pressure due to rising operational costs, increased government scrutiny by various countries in healthcare spending, greater stringency on drug approval and the need for more environmentally sustainable manufacturing practices (Ong \& Mei, 2012). There is a structural problem associated with an innovation drought in biopharmaceutical $\mathrm{R} \& \mathrm{D}$ as shown in a report by Deloitte titled "scenario planning in life sciences R \& D - planning for uncertainty" (2009). In the report, it is explained that global investment in R \& D has increased for the past 20 years, but the output of new drugs or new molecular entities (NME) has been declining. This is mainly due to the rise in significant new drivers of costs. In a separate report by A.T. Kearney (Scheel et al., 2013), during the past 10 years, new molecules output declined steadily from 30 new chemical entity (NCE) per year to 25 NCE per year, while R \& D costs more than doubled. Hence, it is critical to make 
global biomedical R \& D more cost effective and to speed up innovations to translate sustainably research into commercially viable products.

This research study would be useful to companies in the biomedical industry and technology solution vendors, providing in-depth insight into the key factors that impact success in the adoption and usage of e-procurement systems in the biomedical industry. The research would also play a critical role in enabling companies, which may be embarking on an e-procurement project, to understand the critical success factors, as well as the tools and features that should be made available within the e-procurement system.

A two phased approach was adopted for this research. A grounded research was conducted during phase one, involving activities like extensive Internet research, current observations, personal interviews and literature reviews of academic journals. To identify the constructs that are relevant to the impact of e-procurement systems on the biomedical industry, a qualitative research methodology has been adopted. Next, a conceptual model to link the constructs to the impact of e-procurement systems on the biomedical industry was proposed. For the final phase, data collection using survey questionnaire was adopted and the data analysed using SmartPLS. The research focuses on analysing in detail the effect of each parameter on the impact of usage and adoption of e-procurement systems on the biomedical industry as a whole. There are four factors identified in this research: i.e. control and compliance, cost savings, process automation, and improvements and transparency.

\section{MATERIALS AND METHODS}

An initial survey of literature was conducted to acquire an in-depth understanding of the research topic. It follows the guidelines of a grounded research (Glaser \& Strauss, 1967), which involved activities like conducting an extensive survey of literature, referring to knowledge through past observations, web searches, personal interviews and literature reviews from various major academic journals.

Next, the findings of the literature review are tabulated in Table 1, which illustrates the flow of research over the years and the additional value of this research paper in enhancing the ROI (return on investment) of companies in the biomedical industry from adopting an e-procurement system.

The dependent variable identified is "impact of e-procurement systems on biomedical industry". The following are the various independent variables (factors influencing the dependent variable): (1) Cost savings achieved through the adoption of procurement best practices, demand aggregation, elimination of maverick spend and process automation; (2) Process automation and improvements in the form of speedier processing of procurement transactions, reduction of procurement cycle time and integration of procurement business processes; (3) Control and compliance through the enforcement of purchasing limits, centralisation of authority and in the compliance of purchasing processes and workflow; (4) Transparency by preventing corruption, promoting open and fair competition and providing visibility of procurement process and transparency to its vendors.

Insert Table 1 here.

\section{RESEARCH METHODOLOGY}

Upon the completion of the extensive literature survey, the research methodology centred on the already identified core variables, which had appeared repeatedly in the literature survey. In order to comprehend which of these core 
variables are the most dominant, a simple direct relationship between them was used to create the research model.

Table 1

Comparison of Empirical Studies on the Impact of E-Procurement Systems on Biomedical Industry

\begin{tabular}{|c|c|c|c|c|}
\hline $\begin{array}{c}\text { Details of } \\
\text { Literature in } \\
\text { Chronological } \\
\text { Order }\end{array}$ & $\begin{array}{c}\text { Inference on } \\
\text { The Impact of } \\
\text { E-Procurement } \\
\text { Systems on } \\
\text { Biomedical or } \\
\text { other Industry }\end{array}$ & $\begin{array}{c}\text { Importance of } \\
\text { The Parameters } \\
\text { on Adoption of } \\
\text { E-Procurement } \\
\text { Systems in } \\
\text { Biomedical or } \\
\text { other Industry }\end{array}$ & $\begin{array}{c}\text { Detailed } \\
\text { Discussion } \\
\text { on Features } \\
\text { of Each } \\
\text { Parameter }\end{array}$ & $\begin{array}{c}\text { Expectations } \\
\text { from Users } \\
\text { on The A- } \\
\text { doption of E- } \\
\text { Procurement } \\
\text { Systems in } \\
\text { Biomedical } \\
\text { Industry }\end{array}$ \\
\hline $\begin{array}{l}\text { E-Procurement } \\
\text { - Business and } \\
\text { Technical Issues } \\
\text { (Rajkumar, } \\
\text { 2001) }\end{array}$ & $\begin{array}{l}\text { Technologies and } \\
\text { business issues are } \\
\text { the major challenges } \\
\text { in e-procurement } \\
\text { adoption. }\end{array}$ & $\begin{array}{l}\text { Cost savings, speed- } \\
\text { ier processing, deli- } \\
\text { very cycle time re- } \\
\text { duction, accounta- } \\
\text { bility, compliance } \\
\text { (enforcement of } \\
\text { purchasing limits) \& } \\
\text { demand aggregation } \\
\text { are the most import- } \\
\text { ant parameters. }\end{array}$ & $\begin{array}{l}\text { Yes - the parame- } \\
\text { ters are discussed } \\
\text { on the basis of } \\
\text { their importance } \\
\text { rather than the } \\
\text { features. }\end{array}$ & Not analysed. \\
\hline $\begin{array}{l}\text { Using Organiza- } \\
\text { tional Control } \\
\text { Mechanisms to } \\
\text { Enhance Procu- } \\
\text { rement Effici- } \\
\text { ency: How Gla- } \\
\text { xo-Smith-Kline } \\
\text { Improved the } \\
\text { Effectiveness of } \\
\text { E-Procurement } \\
\text { (Kulp et al., } \\
\text { 2006). }\end{array}$ & $\begin{array}{l}\text { Cost savings and } \\
\text { compliance are the } \\
\text { major influences for } \\
\text { e-procurement } \\
\text { adoption. }\end{array}$ & $\begin{array}{l}\text { Cost savings, com- } \\
\text { pliance, control of } \\
\text { spend, efficiency } \\
\text { gains, demand } \\
\text { aggregation and user } \\
\text { friendliness of the } \\
\text { system are the most } \\
\text { important } \\
\text { parameters. }\end{array}$ & $\begin{array}{l}\text { Yes - emphasised } \\
\text { the importance of } \\
\text { factors that lead to } \\
\text { the successful a- } \\
\text { doption of e-pro- } \\
\text { curement: cost } \\
\text { savings through } \\
\text { demand aggrega- } \\
\text { tion, control of } \\
\text { spend and user } \\
\text { friendliness of the } \\
\text { system. }\end{array}$ & Not analysed. \\
\hline $\begin{array}{l}\text { The Performan- } \\
\text { ce Impact of } \\
\text { Implementing } \\
\text { Web-based e- } \\
\text { Procurement } \\
\text { Systems } \\
\text { (Tai et al., 2010). }\end{array}$ & $\begin{array}{l}\text { Transparency, reduc- } \\
\text { tion of order fulfil- } \\
\text { ment cycle time and } \\
\text { cost reduction are } \\
\text { the major influences } \\
\text { for the adoption of } \\
\text { e-procurement } \\
\text { system. }\end{array}$ & $\begin{array}{l}\text { Process automation, } \\
\text { partner relationship, } \\
\text { process integration, } \\
\text { cost reduction, trans- } \\
\text { parency and shorter } \\
\text { order fulfilment } \\
\text { cycle time are the } \\
\text { most important } \\
\text { parameters. }\end{array}$ & $\begin{array}{l}\text { Yes - with specific } \\
\text { focus on partner } \\
\text { relationship and } \\
\text { collaborative } \\
\text { operation. }\end{array}$ & $\begin{array}{l}\text { Not fully } \\
\text { analysed. }\end{array}$ \\
\hline $\begin{array}{l}\text { Removing the } \\
\text { Obstacles to e- } \\
\text { Procurement } \\
\text { Adoption } \\
\text { (Waugh, 2011). }\end{array}$ & $\begin{array}{l}\text { Inter-enterprise } \\
\text { process flow with } \\
\text { third party suppliers } \\
\text { is the key influencer. }\end{array}$ & $\begin{array}{l}\text { Best practices in } \\
\text { procurement, } \\
\text { transparency and } \\
\text { Software as a Service } \\
\text { (SaaS) are the most } \\
\text { important } \\
\text { parameters. }\end{array}$ & $\begin{array}{l}\text { No- only focus } \\
\text { on identifying the } \\
\text { obstacles to adop- } \\
\text { tion of e-procure- } \\
\text { ment and briefly } \\
\text { describe how these } \\
\text { obstacles can be } \\
\text { overcome. }\end{array}$ & Not analysed. \\
\hline $\begin{array}{l}\text { Reining In the } \\
\text { Spend } \\
\text { (Rosenbaum, } \\
\text { 2012). }\end{array}$ & $\begin{array}{l}\text { Cost savings and } \\
\text { centralisation of } \\
\text { procurement } \\
\text { function are the } \\
\text { main influences for } \\
\text { e-procurement } \\
\text { adoption. }\end{array}$ & $\begin{array}{l}\text { Cost savings, ease of } \\
\text { use, accountability, } \\
\text { automation and } \\
\text { spend analysis are } \\
\text { the most important } \\
\text { parameters. }\end{array}$ & $\begin{array}{l}\text { Yes - emphasised } \\
\text { the importance of } \\
\text { ease of use, cost } \\
\text { savings and } \\
\text { process } \\
\text { automation. }\end{array}$ & Not analysed. \\
\hline
\end{tabular}


To be continued from Table 1 .

\begin{tabular}{|c|c|c|c|c|}
\hline $\begin{array}{c}\text { Details of } \\
\text { Literature in } \\
\text { Chronological } \\
\text { Order }\end{array}$ & $\begin{array}{l}\text { Inference on } \\
\text { The Impact of } \\
\text { E-Procurement } \\
\text { Systems on } \\
\text { Biomedical or } \\
\text { other Industry }\end{array}$ & $\begin{array}{l}\text { Importance of } \\
\text { The Parameters } \\
\text { on Adoption of } \\
\text { E-Procurement } \\
\text { Systems in } \\
\text { Biomedical or } \\
\text { other Industry }\end{array}$ & $\begin{array}{c}\text { Detailed } \\
\text { Discussion } \\
\text { on Features } \\
\text { of Each } \\
\text { Parameter }\end{array}$ & $\begin{array}{c}\text { Expectations } \\
\text { from Users } \\
\text { on The A- } \\
\text { doption of E- } \\
\text { Procurement } \\
\text { Systems in } \\
\text { Biomedical } \\
\text { Industry }\end{array}$ \\
\hline $\begin{array}{l}\text { Measuring the } \\
\text { Effectiveness of } \\
\text { e-Procurement : } \\
\text { A Case Discuss- } \\
\text { ion on MCL } \\
\text { (Mahalik, 2012) }\end{array}$ & $\begin{array}{l}\text { Evaluated the ef- } \\
\text { fectiveness of e- } \\
\text { procurement system } \\
\text { with a case analysis } \\
\text { of a public sector } \\
\text { company- Mahanadi } \\
\text { Coal Fields Ltd.- } \\
\text { using the analytical } \\
\text { hierarchy method. }\end{array}$ & $\begin{array}{l}\text { Reduction of } \\
\text { corruption, time } \\
\text { savings and ease of } \\
\text { operation are the } \\
\text { most important } \\
\text { parameters. }\end{array}$ & $\begin{array}{l}\text { Yes - emphasised } \\
\text { the elimination of } \\
\text { maverick spend, } \\
\text { cost reduction, } \\
\text { reduced corruption } \\
\text { and the need for } \\
\text { legal framework. }\end{array}$ & $\begin{array}{l}\text { Not fully } \\
\text { analysed. }\end{array}$ \\
\hline $\begin{array}{l}\text { This research } \\
\text { paper. }\end{array}$ & $\begin{array}{l}\text { Focus on the } \\
\text { detailed study of } \\
\text { core variables. }\end{array}$ & $\begin{array}{l}\text { Users have demon- } \\
\text { strated strong incli- } \\
\text { nation for three out } \\
\text { of four core } \\
\text { variables for the } \\
\text { usage and adoption } \\
\text { of e-procurement } \\
\text { systems for the } \\
\text { biomedical industry. }\end{array}$ & $\begin{array}{l}\text { Yes - extensive } \\
\text { and detailed dis- } \\
\text { cussion under each } \\
\text { of the four core } \\
\text { variables that } \\
\text { would influence } \\
\text { the usage and } \\
\text { adoption of e- } \\
\text { procurement } \\
\text { systems in the bio- } \\
\text { medical industry. }\end{array}$ & $\begin{array}{l}\text { Four existing } \\
\text { core factors } \\
\text { are identified } \\
\text { and inference } \\
\text { is drawn using } \\
\text { extensive } \\
\text { quantitative } \\
\text { survey using } \\
\text { SEM. }\end{array}$ \\
\hline
\end{tabular}

Next, primary data were collected by survey and an initial detailed survey questionnaire was created. The survey questionnaire was then pretested by conducting face to face pilot interviews with five different procurement/biomedical research executives. Further changes like restructuring and reducing the total number of questions and to the survey questionnaire were made after the initial pretesting phase.

Finally, analysis for the data collected from the final survey was carried out. For analysis purposes, SmartPLS was used to construct, run and validate the process model. SmartPLS supports the two sub models in a structural equation model. The structural or inner model specifies the relationship between the independent and dependent latent variables. The measurement model or the outer model specifies the relationship between the constructs or factors and their observed indicators.

\section{Figure 1}

Research Framework

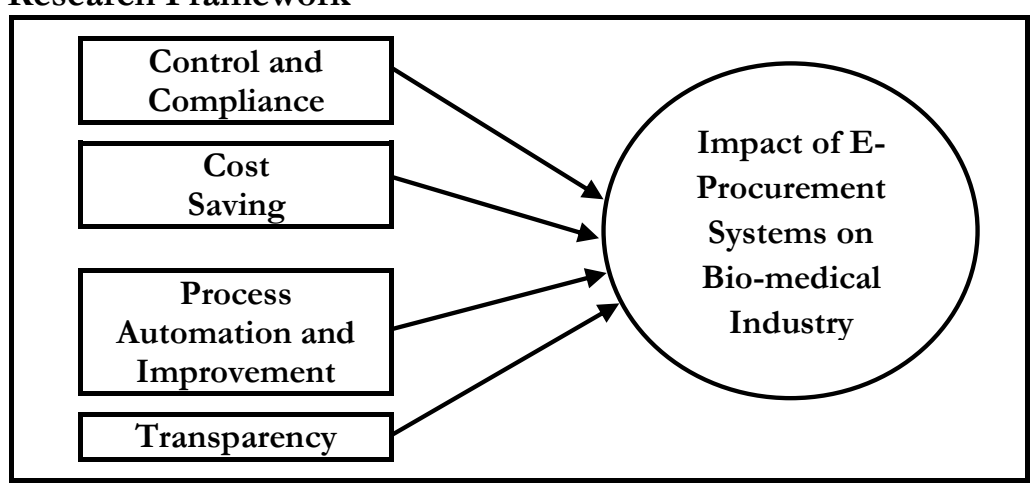




\subsection{Research Framework and Definition of Hypotheses}

Figure 1 is the research framework which was built for this research study. The adoption of e-procurement system (dependent variable) has made a significant impact on the way procurement is conducted in both private and public sectors. Eprocurement is a procedure or a series of activities relating to the buying of goods and services over the Internet. It involves the complete lifecycle from procuring to paying, and by connecting buyers and sellers through electronic means (Mahalik, 2012).

E-Procurement first evolved during the late 1980s, when companies adopted electronic data interchange (EDI) to exchange structured business documents like purchase order and invoice electronically (Weitzel et al., 2000). Global EDI standards like the united nations/electronic data interchange for administration, commerce and transport (UN/EDIFACT) and American National Standards Institute Accredited Standards Committee (ANSI ASC X12) were developed in the mid-1980s and were widely adopted by many industries like automotive, electronics manufacturing and retail (Pupik, 2014) for direct material procurement. Data from EDI can be integrated to backend enterprise resource planning (ERP) systems to reduce costs further (Leonard \& Davis, 2006). On account of the substantial cost of implementing EDI, companies took advantage of the Internet during the mid 1990s to switch to web-EDI (Waltner, 1997). E-procurement solution vendors like Ariba, CommerceOne, free markets, Oracle and SciQuest soon emerged, offering sourcing and purchasing solutions for indirect material or maintenance repair and operating (MRO) supplies. These solution vendors offer procurement e-marketplaces, e-catalogues, e-auction, e-payment and desktop purchasing systems (DPS) (Wening \& Brockmann, 2001).

However, many companies missed the opportunity to cut costs and increase efficiency in their MRO supply chains because MRO materials are often purchased outside the formal purchasing organisation, and user-friendly tools are not available to support this process (Kilpatrick, 2001). Studies conducted have shown that eprocurement can enhance the MRO procurement process and the return on investments. According to Kut Ritchey, partner with Deloitte Consulting, "we've seen studies that show it can be as high as 300 percent over the lifetime of a system". Other studies have shown that GlaxoSmithKline (GSK) saved approximately $\$ 2.0$ million in the first 12 months, after it had implemented an Ariba electronic ordering system and simultaneously installed SciQuest's Spend Director (Kulp et al., 2006).

One of the issues of e-procurement systems is the inability to integrate data back to the ERP or inventory management system (Rajkumar, 2001).Problems with integration to backend systems, which may have incompatible platforms, are a major hurdle to many e-procurement efforts. Some companies use several ERP systems, which are not compatible with one another. Suppliers need to be able to handle different e-procurement systems which their customers are using. Ariba, i2 and CommerceOne, for instance, each have their own specific proprietary formats (Bedell, 2002). Furthermore, suppliers also find it hard to participate in e-procurement initiatives as they do not believe they can reap the full benefits for their investments. Hence, suppliers are reluctant to participate in such e-procurement programmes that are initiated by their customers, and even if they do so, it is only with their most strategic or largest customers (Rajkumar, 2001).

One of the recommendations to overcome the high initial costs to set up an eprocurement system is to adopt a pay-per-use or a SaaS model - where such systems are made available and securely and reliably hosted on the Cloud (Waugh, 2011). SaaS solutions also significantly remove the obstacle of limited IT resources in organisations, 
by reducing the large amount of time that had been spent in maintaining supplier catalogues.

\subsection{Control and Compliance}

In 2003, pharmaceutical company GSK would have saved another 20 to $30 \%$ (between $\$ 80$ and $\$ 120$ million) in indirect material purchases if it had complied fully with its procurement processes (Kulp et al., 2006). As a result of these losses, the enforcement on the use of pre-negotiated contracts has been made the top priority in GSK. According to a 2009 Aberdeen group study, by bringing more non payroll, tax, tariff and other fee related spend under the management of a central dedicated group, companies could achieve an estimated $5 \%$ to $20 \%$ cost savings for each new dollar of spend brought under management.

The hypotheses follow from the above discussion:

Hypothesis $1\left(\mathbf{H}_{1}\right)$ : control and compliance will have a positive effect on cost savings as spend management is being governed centrally.

Hypothesis $2\left(\mathbf{H}_{2}\right)$ : control and compliance, resulting from the enforcement of purchasing limits, centralisation of authority and compliance with purchasing process, will have a positive impact on the adoption and usage of e-procurement systems in the biomedical industry.

Hypothesis $3\left(\mathbf{H}_{3}\right)$ : control and compliance will have a positive effect on transparency by enforcing the purchasing limits and controlling the purchasing process by implementing purchasing approval workflow.

\subsection{Cost Savings}

Many procurement executives believe that one of the long-term benefits of eprocurement would be the freeing of resources from manual order processing and redeploying them for other activities like strategic sourcing (Rajkumar, 2001). Businesses can enjoy the benefits of implementing e-procurement by adopting best practices like electronic order processing, bar coding, procurement cards and blanket order system (Roth, 2001). The Internet-based nature of e-procurement eliminates the need for IT support of traditional software, supports ease of maintenance of all master data stored in a central database and makes the procure to pay cycle "almost instantaneous...from as much as two weeks to under an hour," according to Chea Simm, business development manager at Compusearch (Bedell, 2002).

E-procurement can reduce material and service costs for $\mathrm{MRO}$ goods and services by about 5 to $10 \%$ by reducing maverick spend, defining the use of approved suppliers and providing better leverage for contract negotiations (Aisbett et al., 2005). By aggregating the spend of different divisions within an organisation, e-procurement allows companies to have complete control and visibility of enterprise spending (Moore, 2007). E-procurement systems provide a variety of new options for procuring materials. "Different products may call for different solutions," stated Ritcey of Deloitte Consulting. "So, one company could conceivably use electronic data exchange to source capital inputs or raw materials, a supplier's self-service catalogue for office suppliers, a buying network for, say, paper stock or certain chemicals, an online auction site to book cheap cargo rates with a carrier that has extra space and perhaps a multisupplier mall just to browse for even better deals" (DelGaudio, 2004). Tangible savings can be realised through process automation, by automating and radically improving the buying and approving processes (Rosenbaum, 2012). 
One popular procurement best practice - supplier portals forming a critical part of e-procurement systems - is no longer simply good to have. These multi-enterprise solutions are now a critical supply chain management, as reported by Gartner in 2013.

The hypothesis follows from the above discussion:

Hypothesis $4\left(\mathbf{H}_{4}\right)$ : cost savings, resulting from adopting procurement best practices, demand aggregation, elimination of maverick spend and process automation, will have a positive impact on the adoption and usage of e-procurement systems in the biomedical industry.

\subsection{Process Automation and Improvements}

Web-based electronic commerce offers a way to increase efficiency and competitive advantage (Carter et al., 2000). A research conducted by Aberdeen in 2011 on organisations' experiences with Internet-based procurement automation technologies suggests that companies have been able to achieve significant cost and process benefits by automating key procurement activities. Many organisations are incorporating e-business strategies in their supply chain management practices by conducting electronic commerce over the Internet. By doing so, these companies can create a competitive advantage and enjoy the benefits of cost reduction and efficiency improvements, as well as increase in data accuracy, faster processing and delivery (Rajkumar, 2001).

E-procurement enables companies to maintain lean inventory levels, since the ERP systems can be linked to suppliers' backend systems, and minimum threshold levels set, at which suppliers will automatically self-replenish the inventory levels (Moore, 2007).

The hypotheses follow from the above discussion:

Hypothesis $\mathbf{5}\left(\mathbf{H}_{5}\right)$ : process automation and improvements, resulting from speedier processing, reduction of procurement cycle time and process integration, will have a positive impact on the usage and adoption of e-procurement systems in the biomedical industry.

Hypothesis $6\left(\mathbf{H}_{\mathbf{6}}\right)$ : process automation and improvements will have a positive effect on control and compliance through the standardisation of procurement workflow and processes.

Hypothesis $7\left(\mathbf{H}_{7}\right)$ : process automation and improvements will have a positive effect on cost savings by eliminating manual work and avoiding data reentry into different backend systems.

\subsection{Transparency}

E-procurement enables companies to make better decisions related to rationalising their supplier base by providing a broad overview of the market. Eprocurement system provides new levels of visibility to the chief financial officers (CFOs) and finance directors about what the company is buying and from whom. CFOs can have confidence that employees are adhering to corporate negotiated contracts made with suppliers, have direct visibility on spending trends and negotiate better prices on future contracts (Bedell, 2002). Internet based e-procurement systems can create greater transparency in public spending, enhance process efficiency and achieve commodity savings (Waugh, 2011). Governments procure goods and services in order to preserve accountability and maintain transparency. They deploy a structured and complex system to protect the public interest (Rasheed, 2004). As per the transparency international (2011) of EU and futuregov.asia, a research group, public sector organisations use e-procurement for contracts to achieve benefits, such as 
increased efficiency and cost savings in government procurement and improved transparency (to reduce corruption) in procurement services.

The hypotheses follow from the above discussion:

Hypothesis $\mathbf{8}\left(\mathbf{H}_{8}\right)$ : transparency, resulting from the prevention of corruption, promoting open and fair competition and providing visibility of the procurement and tender award process, will have a positive impact on the usage and adoption of e-procurement systems in the biomedical industry.

Hypothesis $9\left(\mathbf{H}_{\mathbf{9}}\right)$ : transparency will have a positive effect on cost savings, as it allows organisations to trace past spending trends and patterns, so as to negotiate better prices on future contracts.

\subsection{Data Collection}

A survey was used for data collection. A pilot survey was first pretested with five procurement/biomedical research executives before official administration of the survey questionnaire. The survey began with a note to inform the respondent of the purpose of this survey and reassured the participant that confidentiality of the responses would be maintained. The pilot survey was developed by framing relevant questions under each of the four core variables identified from the literature survey. The survey provided both qualitative and quantitative questions for the core variables identified.

The questionnaire was structured into two parts. Part one collected respondents' demographic and other details like gender and years of working experience. The second part captured users' expectation for the usage and adoption of e-procurement systems for the biomedical industry. For each latent variable, three to five questions, serving as measurable indicators, were developed in order to capture the usage and impact of eprocurement systems on biomedical industry. All the observed indicators were measured using Likert scale comprising five points, with scales being "strongly disagree" to "strongly agree". The collection of the data was done through an online survey provided by Google Docs.

The final survey questionnaire was administered to the supply chain Asia (SCA), Singapore logistics association (SLA) and the BioSingapore association, for distribution to their member communities. SCA has about 2000 online community subscribers, SLA has about 510 member companies and BioSingapore has more than 100 member companies. The participants are mainly based in Singapore, some of whom work for multinational companies with strong presence in Asia Pacific. Out of a potential 2600 participants, 298 responded positively. After editing, 218 Responses were found useful. The response rate was about $12 \%$. There was no incomplete response because all the questions were mandatory. Finally, there were 218 Complete and usable responses. Table 2 provides a summary of the demography profile and characteristics of the respondents. In order to detect any potential bias in the respondents' answers, we compare the demography and other characteristics like gender, years of working experience in existing company and the job role of the respondents.

Insert Table 2 here.

\subsection{Data Analysis}

In order to validate the measurements and to test the developed hypotheses, the SmartPLS software (Ringle et al., 2005) was utilised. Structural equation modelling (SEM) is a second generation multivariate data analysis method and is often deployed in marketing research (Hennig-Thurau et al., 2007) because it can test theoretically 
supported linear and additive causal models (Haenlein \& Kaplan, 2004). PLS is also useful for structural equation modelling in applied research projects especially where participants are limited and the data distribution is skewed (Wong, 2011).

The outer model, which is also known as the measurement model, is first tested for construct validity. This is followed by testing the hypotheses using the inner model, which is also known as the structural model (Henseler \& Sarstedt, 2013).

The SmartPLS software (Ringle et al., 2005) is used to create the path model and validate the reliability of the latent constructs and the model. Next, a bootstrapping procedure is applied to 218 samples to generate the corresponding t-values (or tstatistics) for significance testing of the structural path for both the inner and outer models.

Table 2

Demography Characteristics of Respondents

\begin{tabular}{lcc}
\hline Survey participants (n= 298) & No. of Respondents & Percentage \\
\hline Gender & 129 & \\
Female & 169 & $43 \%$ \\
Male & & $57 \%$ \\
Number of years worked in existing organisation & & \\
Less than 6 months & 17 & $6 \%$ \\
6 months to 1 year & 21 & $7 \%$ \\
1 to 2 years & 49 & $16 \%$ \\
3 to 5 years & 73 & $24 \%$ \\
More than 5 years & 138 & $46 \%$ \\
Size of Company & & \\
10 or fewer employees & 23 & $8 \%$ \\
11 to 50 employees & 37 & $12 \%$ \\
51 to 100 employees & 21 & $7 \%$ \\
100 to 500 employees & 39 & $13 \%$ \\
$500+$ employees & 178 & $61 \%$ \\
Job Role & & \\
Business development/sales \& marketing & 77 & $26 \%$ \\
Operation management & 80 & $27 \%$ \\
Purchasing/procurement & 38 & $13 \%$ \\
Research and development & 42 & $14 \%$ \\
Others & 61 & $20 \%$ \\
Industry Type & & \\
Biomedical Science/Research & 43 & $14 \%$ \\
Consumer Goods & 23 & $8 \%$ \\
Financial Services/Insurance & 39 & $13 \%$ \\
Healthcare/Pharmaceutical & 41 & $14 \%$ \\
Information Tech. or Services/Communications & 46 & $15 \%$ \\
Logistics/Transportation & 24 & $8 \%$ \\
Manufacturing & 28 & $9 \%$ \\
Travel/Hospitality & 23 & $8 \%$ \\
Others & 31 & $10 \%$ \\
\hline
\end{tabular}

\section{RESULTS}

\subsection{Reliability Validation}

Both the Cronbach's alpha and composite reliability scores are utilised to evaluate the consistency and reliability of the research measurements. As a rule of thumb, internal consistency is established when the Cronbach's alpha scores are larger 
than the recommended value of 0.6 (Hair et al., 2012). Internal consistency is considered good when both the Cronbach's alpha and composite reliability scores are above the minimum recommended value of 0.7 (Nunnally, 1978; Kline, 2000; and George \& Mallery, 2003). According to Bagozzi and Yi (1988), the composite reliability could be a replacement for Cronbach's alpha. The results in Table 3 show that the composite reliability scores are all higher than 0.8 , and the Cronbach's alpha values are all greater than 0.7 . Therefore, the model is considered reliable, as it exhibits high levels of internal consistency reliability in all five latent variables.

Table 3

Reliability and Validity Analysis

\begin{tabular}{|c|c|c|c|c|c|}
\hline Overview & AVE & $\begin{array}{l}\text { Composite } \\
\text { Reliability }\end{array}$ & $\begin{array}{c}\text { Cronbach's } \\
\text { Alpha }\end{array}$ & $\begin{array}{c}\mathbf{R} \\
\text { Square }\end{array}$ & $\begin{array}{l}\text { LV index } \\
\text { Variables }\end{array}$ \\
\hline $\begin{array}{l}\text { Impact of e-Procure- } \\
\text { ment Systems on Bio- } \\
\text { medical Industry }\end{array}$ & 0.557 & 0.883 & 0.841 & 0.480 & 4.174 \\
\hline Cost Savings & 0.625 & 0.833 & 0.701 & 0.485 & 4.255 \\
\hline $\begin{array}{l}\text { Process Automation } \\
\text { and Improvements }\end{array}$ & 0.725 & 0.888 & 0.810 & 0.000 & 4.184 \\
\hline $\begin{array}{l}\text { Control and Compli- } \\
\text { ance }\end{array}$ & 0.659 & 0.853 & 0.741 & 0.309 & 4.193 \\
\hline Transparency & 0.668 & 0.858 & 0.757 & 0.436 & 4.152 \\
\hline
\end{tabular}

\subsection{Convergent Validity}

Convergent validity can be defined as the extent to which the scores on one measure are related to scores collected from a similar or different measure. It is also one of the means to test the construct validity (Fornell \& Larcker, 1981; Straub et al., 2004). AVE measures the variance captured by a latentconstruct, that is, the explained variance. For each specific construct, it shows the ratio of thesum of its measurement item variance as extracted by the construct relative to the measurement error attributed to its items (Gefen \& Straub, 2005). In testing convergent validity, each item's average variance extracted (AVE) should be 0.50 or higher (Dillion \& Goldstein, 1984; Bagozzi $\& \mathrm{Yi}, 1988)$. It is also recommended that the loading for each item is more than 0.70 (Chin et al., 2003). Table 3 shows that the AVE value for each item is above 0.55, and, as can be seen in Table 4, the value of each item's loading (indicator reliability) is above 0.7. These two tests establish the convergent validity of the model. Finally, in Table 5, while matching the item-to-construct correlation against the correlations with other constructs, the results show that the indicators belong to the highlighted constructs only and never to the other constructs.

Insert Table 4 here.

\subsection{Discriminant Validity}

According to Gefen and Straub (2005), other than convergent validity, measuring the discriminant validity is equally important in order to determine the validity of a construct. Discriminant validity is established when each measurement item demonstrates weak correlation with all the rest of the other constructs except the one which it is theoretically related to.

Discriminant validity can be established if the value of the square root of the AVE for each of the latent constructs is higher than correlation values of the other latent constructs or variables (Fornell \& Larcker, 1981). Hence, the square root of the AVE had been calculated and highlighted in bold and reflected diagonally across the table (see Table 5). 
Table 4

Summary of Results for Reflective Outer Models

\begin{tabular}{|c|c|c|c|c|c|c|}
\hline Construct & Item Definition & $\begin{array}{c}\text { Loadings } \\
\text { (Indicator } \\
\text { Reliabili- } \\
\text { ty) } \\
\end{array}$ & AVE & $\begin{array}{c}\text { Compo- } \\
\text { site } \\
\text { Relia- } \\
\text { bility } \\
\end{array}$ & $\begin{array}{l}\text { Cron- } \\
\text { bach's } \\
\text { Alpha }\end{array}$ & $\begin{array}{c}\mathbf{R} \\
\text { Square }\end{array}$ \\
\hline Impact of e- & Accuracy of data & 0.786 & 0.557 & 0.883 & 0.849 & 0.480 \\
\hline \multirow{5}{*}{$\begin{array}{l}\text { Procure- } \\
\text { ment Sys- } \\
\text { tems on } \\
\text { Biomedical } \\
\text { Industry }\end{array}$} & Business analytics & 0.731 & & & & \\
\hline & Content & 0.718 & & & & \\
\hline & Ease of use & 0.760 & & & & \\
\hline & $\begin{array}{l}\text { Strengthen supply } \\
\text { chain }\end{array}$ & 0.724 & & & & \\
\hline & $\begin{array}{l}\text { Timeliness of } \\
\text { information }\end{array}$ & 0.757 & & & & \\
\hline \multirow{3}{*}{$\begin{array}{l}\text { Cost } \\
\text { Savings }\end{array}$} & Best practices & 0.827 & 0.625 & 0.833 & 0.701 & 0.485 \\
\hline & $\begin{array}{l}\text { Demand } \\
\text { aggregation }\end{array}$ & 0.730 & & & & \\
\hline & $\begin{array}{l}\text { Process } \\
\text { automation }\end{array}$ & 0.811 & & & & \\
\hline \multirow{6}{*}{$\begin{array}{l}\text { Process } \\
\text { Automation } \\
\text { and Impro- } \\
\text { vements } \\
\text { Control and } \\
\text { Compliance }\end{array}$} & Process integration & 0.832 & 0.725 & 0.888 & 0.820 & \\
\hline & Reduce cycle time & 0.872 & & & & \\
\hline & $\begin{array}{l}\text { Speedier } \\
\text { processing }\end{array}$ & 0.849 & & & & \\
\hline & $\begin{array}{l}\text { Centralisation of } \\
\text { authority }\end{array}$ & 0.764 & 0.659 & 0.853 & 0.741 & 0.309 \\
\hline & $\begin{array}{l}\text { Comply with } \\
\text { purchasing process }\end{array}$ & 0.826 & & & & \\
\hline & $\begin{array}{l}\text { Enforce purchase } \\
\text { limits }\end{array}$ & 0.843 & & & & \\
\hline \multirow[t]{3}{*}{$\begin{array}{l}\text { Transparen- } \\
\text { cy }\end{array}$} & $\begin{array}{l}\text { Prevents } \\
\text { corruption }\end{array}$ & 0.848 & 0.668 & 0.858 & 0.757 & 0.436 \\
\hline & $\begin{array}{l}\text { Open and fair } \\
\text { competition }\end{array}$ & 0.754 & & & & \\
\hline & Visibility in spend & 0.847 & & & & \\
\hline
\end{tabular}

Table 5

Data Analysis to Establish Discriminant Validity

\begin{tabular}{lccccc}
\hline \multicolumn{1}{c}{ Construct } & $\begin{array}{c}\text { Impact of e- } \\
\text { Procurement } \\
\text { Systems on } \\
\text { Biomedical } \\
\text { Industry }\end{array}$ & $\begin{array}{c}\text { Cost } \\
\text { Savings }\end{array}$ & $\begin{array}{c}\text { Process } \\
\text { Automation } \\
\text { and } \\
\text { Improvements }\end{array}$ & $\begin{array}{c}\text { Control and } \\
\text { Compliance }\end{array}$ & $\begin{array}{c}\text { Transpa- } \\
\text { rency }\end{array}$ \\
\hline $\begin{array}{l}\text { Impact of e- } \\
\begin{array}{l}\text { Procurement } \\
\text { Systems on }\end{array}\end{array}$ & $\mathbf{0 . 7 4 6}$ & & & & \\
$\begin{array}{l}\text { Biomedical } \\
\text { Industry }\end{array}$ & 0.477 & $\mathbf{0 . 7 9 0}$ & & & \\
$\begin{array}{l}\text { Cost Savings } \\
\text { Process } \\
\text { Automation and }\end{array}$ & 0.498 & 0.611 & $\mathbf{0 . 7 4 6}$ & & \\
$\begin{array}{l}\text { Improvements } \\
\text { Control and } \\
\text { Compliance }\end{array}$ & 0.632 & 0.589 & 0.495 & $\mathbf{0 . 8 1 2}$ & \\
Transparency & 0.608 & 0.551 & 0.501 & 0.661 & $\mathbf{0 . 8 1 7}$ \\
\hline
\end{tabular}




\subsection{Structural Model Analysis}

The developed hypotheses were then tested by generating t-statistics using SmartPLS software. A bootstrapping re-sampling procedure (Mooney \& Duval, 1993; Manski, 1996; and Wetzels et al., 2009) of 218 samples was conducted to determine the significance level of the paths defined within the structural model. Bootstrapping results in a larger sample which is claimed to model the unknown population (Hesterberg et al., 2003). The generated t-statistics (t-value) values demonstrate the level of significance for each of the hypotheses. A $5 \%$ significance level $(p<0.10)$ is used as a statistical criterion, and the path coefficient is considered significant if the t-value is larger than 1.96 (Neyman \& Pearson, 1933; Cowles \& Davis, 1982). Also, for a significance level of $10 \%$, t-value should be greater than 1.65 and 2.59 for a significance level of $1 \%$.

Insert Table 6 here.

Of the nine hypotheses, eight are supported. As observed, hypothesis $\mathrm{H}_{1}$ is supported because the path from control and compliance to cost savings is significant $(b=0.250, p<0.01)$. This is because costs savings can be reaped if procurement are managed and governed centrally. The paths from control and compliance to impact of e-procurement systems $(b=0.342, p<0.01)$ and to transparency $(b=0.661, p<0.01)$ are significant, which strongly supports hypotheses $\mathrm{H}_{2}$ and $\mathrm{H}_{3}$ respectively. This indicates that compliance with purchasing process and enforcing purchasing limits will have a positive impact on the adoption of e-procurement systems and achieve transparency.

Hypothesis $4(\mathrm{~b}=0.023, \mathrm{p}>0.1)$ is not supported from cost savings to impact of e-procurement systems because cost savings may take time to achieve and also due to the high initial upfront costs incurred from implementing the system.

Hypothesis $5(\mathrm{~b}=0.556, \mathrm{p}<0.01)$ and hypothesis $6(\mathrm{~b}=0.373, \mathrm{p}<0.01)$ are both strongly supported because process automation and improvements, resulting from the reduction of procurement cycle time will have a positive impact on the adoption of eprocurement. Similarly, process automation (through the standardisation of procurement workflow and processes) will achieve control and compliance.

Hypothesis $7(b=0.146, p<0.05)$ is supported from process automation and improvements to cost savings as procurement processes become automated. Cost savings as a result of automating the procurement process can reduce the average cost of processing a purchase order by between $\$ 10$ and $\$ 40$ (Aisbett et al., 2005).

Hypothesis $8(\mathrm{~b}=0.199, \mathrm{p}<0.01)$ is also supported from transparency to the impact of e-procurement systems as a result of preventing corruption, promoting open and fair competition and providing clear visibility of the procurement and tender award process.

Hypothesis 9 is supported because the path from transparency to cost savings is significant $(b=0.297, \mathrm{p}<0.01)$. This is because costs savings can be achieved if organisations were able to trace past spending trends and patterns, so as to negotiate better prices on future contracts. Figure 2 and 3 show the results of our PLS structured model.

Insert Figure 2 here. 
Table 6

Data Analysis to the Developed Hypotheses

\begin{tabular}{|c|c|c|c|c|c|c|c|c|}
\hline & $\begin{array}{l}\text { Hypothesis } \\
\text { Description }\end{array}$ & $\begin{array}{l}\text { Path } \\
\text { Coeffi } \\
\text {-cient }\end{array}$ & Mean & $\begin{array}{l}\text { Std. } \\
\text { Deviati- } \\
\text { on }\end{array}$ & $\begin{array}{l}\text { Std. } \\
\text { Error }\end{array}$ & $\begin{array}{c}\text { T- } \\
\text { Statis- } \\
\text { tics (T- } \\
\text { Value) }\end{array}$ & $\begin{array}{l}\text { Signifi- } \\
\text { cance } \\
\text { (one- } \\
\text { tailed) }\end{array}$ & $\begin{array}{c}\text { Suppor- } \\
\text { ted } \\
(\mathrm{Y} / \mathrm{N})\end{array}$ \\
\hline $\mathbf{H}_{1}$ & $\begin{array}{l}\text { Control and } \\
\text { Compliance } \\
\rightarrow \text { Cost Savings }\end{array}$ & 0.250 & 0.260 & 0.0873 & 0.0873 & 2.869 & $\mathrm{p}<0.01$ & Yes \\
\hline $\mathbf{H}_{2}$ & $\begin{array}{l}\text { Control and } \\
\text { Compliance } \\
\rightarrow \text { Impact of e- } \\
\text { Procurement } \\
\text { Systems on } \\
\text { Biomedical } \\
\text { Industry }\end{array}$ & 0.342 & 0.348 & 0.0792 & 0.0792 & 4.318 & $\mathrm{p}<0.01$ & Yes \\
\hline $\mathbf{H}_{3}$ & $\begin{array}{l}\text { Control and } \\
\text { Compliance } \rightarrow \\
\text { Transparency }\end{array}$ & 0.661 & 0.666 & 0.0349 & 0.0349 & 18.930 & $\mathrm{p}<0.01$ & Yes \\
\hline $\mathbf{H}_{4}$ & $\begin{array}{l}\text { Cost Savings } \rightarrow \\
\text { Impact of e- } \\
\text { Procurement } \\
\text { Systems on } \\
\text { Biomedical } \\
\text { Industry }\end{array}$ & 0.023 & 0.020 & 0.0832 & 0.0832 & $\mathrm{FF} 0.272$ & $\begin{array}{l}\text { Not } \\
\text { support- } \\
\text { ed }\end{array}$ & No \\
\hline $\mathbf{H}_{5}$ & $\begin{array}{l}\text { Process Auto- } \\
\text { mation and } \\
\text { Improvements } \\
\rightarrow \text { Impact of e- } \\
\text { Procurement } \\
\text { Systems on } \\
\text { Biomedical } \\
\text { Industry }\end{array}$ & 0.556 & 0.560 & 0.0577 & 0.0577 & 9.630 & $\mathrm{p}<0.01$ & Yes \\
\hline $\mathbf{H}_{6}$ & $\begin{array}{l}\text { Process Auto- } \\
\text { mation and } \\
\text { Improvements } \\
\rightarrow \text { Control and } \\
\text { Compliance }\end{array}$ & 0.373 & 0.364 & 0.0706 & 0.0706 & 5.279 & $\mathrm{p}<0.01$ & Yes \\
\hline $\mathbf{H}_{7}$ & $\begin{array}{l}\text { Process Auto- } \\
\text { mation and } \\
\text { Improvements } \\
\rightarrow \text { Cost Savings }\end{array}$ & 0.146 & 0.146 & 0.079 & 0.079 & 1.846 & $\mathrm{p}<0.05$ & Yes \\
\hline $\mathbf{H}_{8}$ & $\begin{array}{l}\text { Transparency } \\
\rightarrow \text { Impact of e- } \\
\text { Procurement } \\
\text { Systems on } \\
\text { Biomedical } \\
\text { Industry }\end{array}$ & 0.199 & 0.197 & 0.0745 & 0.0745 & 2.673 & $\mathrm{p}<0.01$ & Yes \\
\hline $\mathbf{H}_{9}$ & $\begin{array}{l}\text { Transparency } \rightarrow \\
\text { Cost Savings }\end{array}$ & 0.297 & 0.295 & 0.0681 & 0.0681 & 4.351 & $\mathrm{p}<0.01$ & Yes \\
\hline
\end{tabular}


Figure 2

Results of PLS Structural Model Analysis (Extracted from SmartPLS)

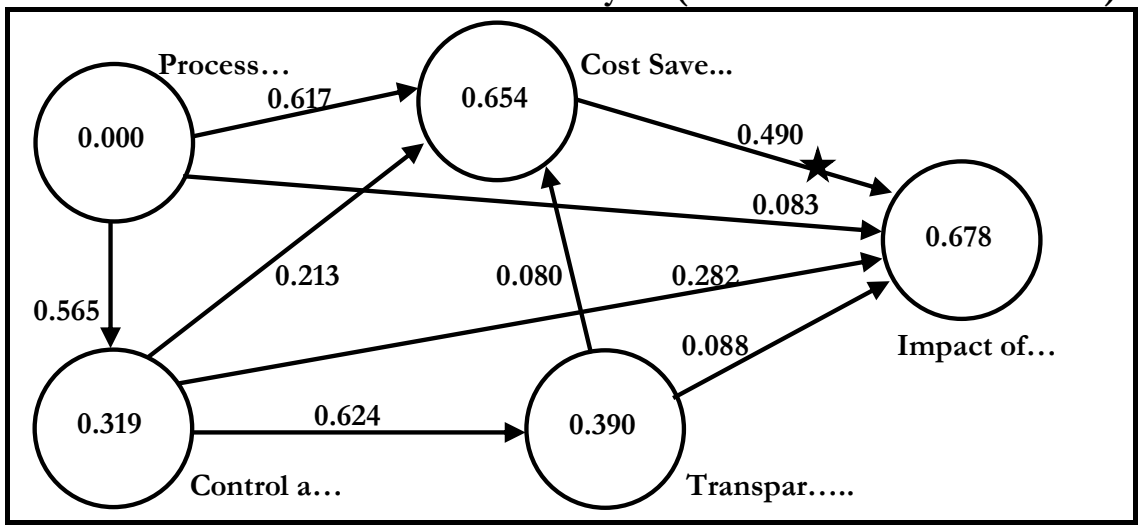

Note: the star represents the one hypothesis which is not supported.

Figure 3

Results of the PLS Structural Model Analysis

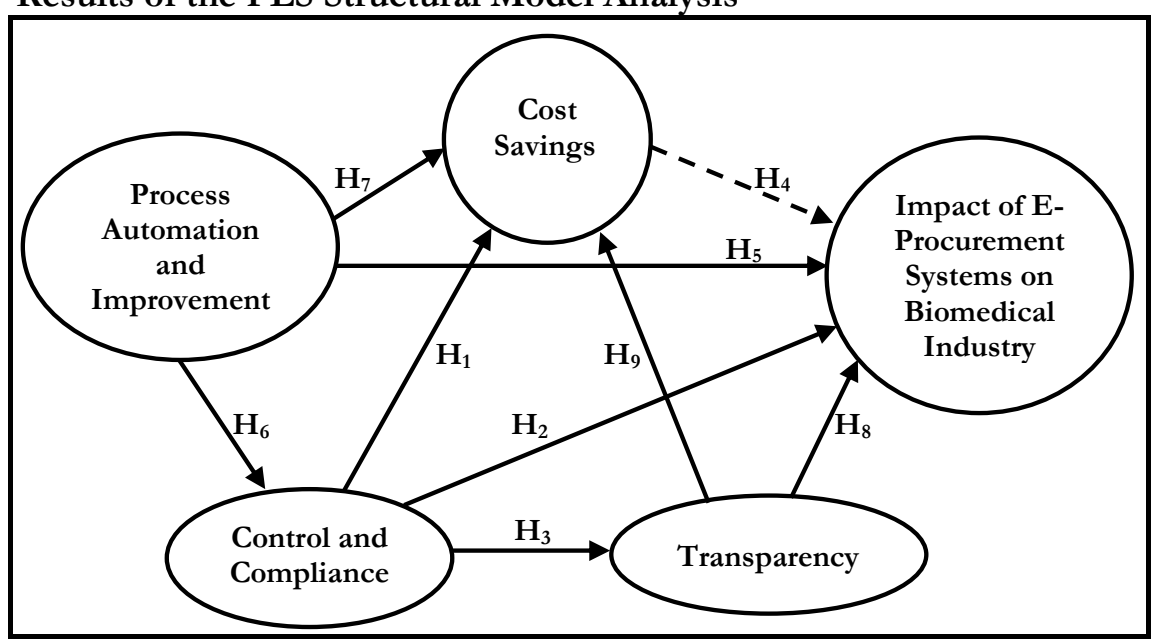

Note: significant relationship $(\rightarrow)$, insignificant relationship $(\cdots \bullet)$.

\subsection{Implications for the Industry}

The focus of this study centred on the core variables and the key factors that would impact the success in the adoption of e-procurement systems in the biomedical industry. Companies in the biomedical and other industries, the supplier/vendor community and e-procurement technology providers can leverage this research to gain insights into the key factors and motivation for companies to adopt an e-procurement system.

Contrary to popular belief, cost saving is not the top motivation for companies to adopt an e-procurement system. One possible explanation is that software products do not solve the problem of inefficient business processes, people do (Rosenbaum, 2012). Hence, the e-procurement software or system should not be used merely to automate an inefficient process. One of the top barriers to e-procurement adoption in the public sector are the high implementation costs, made worse by existing tight budgetary measures (Waugh, 2011). The costs to implement e-procurement could be quite significant, and the returns from investment could take more than three years (Rajkumar, 2001). 
It was widely perceived that demand aggregation would help organisations leverage its buying power with prospective suppliers. However, aggregation of demand remains a major obstacle because of vested departmental interests, perceived loss of authority and effort required in achieving it (Panda \& Sahu, 2011).

Process automation and improvements constituted the topmost motivation for companies to adopt e-procurement systems. There is an obvious need for organisations to improve and optimise their operational efficiency and business processes (Tai et al., 2010). Automating the existing business process would not reap the full benefits of eprocurement technology. The organisation needs to undergo business process reengineering in order realise the full potential of cost savings and process efficiencies (Rajkumar, 2001).

The other major finding of this study is that control and compliance (second major factor) has a strong positive impact on the usage and adoption of e-procurement systems in the biomedical industry. The research study also identified the ability to enforce purchasing limits as the most significant factor, followed by the compliance to purchasing process and centralising the purchasing function. Industry players offering e-procurement solutions should focus on providing easy to use features like the ability to configure business processes, for example, to purchase requisition approval through a workflow system. The system should also have the ability to set and enforce purchasing limits either by product category or department basis. The ability to support a centralised procurement model is also extremely important.

The next finding is that process automation and improvements has a significant impact on control and compliance. This is because a full integration into the organisation's backend ERP and other subsystem is a prerequisite which will automate business processes and eliminate manual data re-entry. Hence, technology solution providers should offer software solutions that are open, interoperable and able to integrate easily with any ERP software or systems.

\section{LIMITATIONS AND SCOPE FOR FURTHER RESEARCH}

One recommendation for further research is to obtain a more global geographical perspective by widening the coverage of the biomedical industry to the United States (US) and Europe (Germany, Poland and United Kingdom). Respondents or companies operating in the US or Europe may offer differing insights or behaviour against those operating in Asia.

With the widespread adoption of enterprise cloud technology, another recommendation would be to conduct further research into factors that influence the adoption of SaaS or cloud-based e-procurement solution (for example, Coupa who build their entire suite of applications on Public cloud like Amazon.com) versus the adoption of the software model (for example, SAP SRM - supplier relationship manager).

The other possible scope for future research would be to examine the impact of e-procurement systems on small and medium enterprises (SMEs). Does e-procurement only benefit big organisations or does it also benefit SMEs?

The final recommendation is to research and analyse the functional areas which an e-procurement system should offer, and that would deliver the most compelling benefits in terms of cost savings. Examples of some of the functional areas are auction, contract management, electronic invoicing, mobile procurement, purchase requisitions, spend analysis, supplier network, sourcing and tendering. 


\section{CONCLUSION}

The research has uncovered the many business and technical challenges companies face in the adoption and implementation of e-procurement systems in the biomedical industry. Despite these challenges, e-procurement has become a significant strategy of most companies' e-business. In a 2012 report by Aberdeen, supplier networks also formed an integral part of the e-procurement ecosystem. The report also revealed how the functionality of supplier networks expanded beyond the traditional perceptions of transaction centred vehicles for procurement.

The four factors, namely, cost savings, process automation and improvements, control and compliance and transparency, were methodically analysed to gauge their influence and significance to the success of adopting and using e-procurement systems in the biomedical industry.

Based on this research paper, there is a noticeable paradigm shift in the factors identified that impact the adoption of e-procurement systems in the biomedical industry. Cost savings and transparency are now perceived to be given factors or "must haves" in the adoption of e-procurement systems and not considered to be a differentiator for companies to adopt e-procurement. Instead, it has been observed that process automation and improvements is the biggest factor for companies to adopt eprocurement systems, followed by control and compliance.

Although cost savings and transparency are not the biggest factors for companies to adopt e-procurement, both of these still have a positive impact on the usage and successful adoption of e-procurement systems in the biomedical industry. This observation is supported by report articles from Kulp et al. (2006) and Rosenbaum (2012).

The research also discovered that the ability to perform business analytics and strengthen supply chain management are the most important factors in measuring success in the adoption of e-procurement systems in the biomedical industry.

Based on this research, it can be foreseen that the adoption of e-procurement systems will continue to increase in all sectors of the industry and bring tremendous benefits not only to the biomedical industry, but also to the other industry sectors.

\section{REFERENCES}

Adams, R., Bergfors, M., \& Wilson, D. R. (2013). Magic quadrant for strategic sourcing application suites. Gartner, Inc. Retrieved May 1, 2014, from https://www.bravosolution.com/cms/uk/resource-library/industry-reports-1/ 2013-gartner-magic-quadrant-for-strategic-sourcing.

Agi, M., Ballot, E., \& Molet, H. (2005). 100\% EDI-connected suppliers projects: An empirical investigation of success factors. Journal of Purchasing \& Supply Management, 11(1), 107-115.

Aisbett, J., Lasch, R., \& Pires, G. (2005). A decision-making framework for adoption of e-procurement. International Journal of Integrated Supply Management, 1(3), 278-293.

Bagozzi, R. P., \& Yi, Y. (1988). On the evaluation of structural equation models. Journal of the Academy of Marketing Science, 16(1), 74-94.

Bedell, D. (2002). Solving the headaches of eprocurement. Corporate Finance, 210, 24-27.

Carabello, L. (2001). E-procurement can reduce expenses (digital perspectives). Healthcare Financial Management, 55(12), 82-84.

Carter, P. L., Carter, J. R., Monczka, R. M., Slaight, T. H., \& Swan, A. J. (2000). The future of purchasing and supply: A ten-year forecast. Journal of Supply Chain Management, 36(1), 14-26. 
Chin, W. W., Marcolin, B. L., \& Newsted, P. R. (2003). A partial least squares latent variable modeling approach for measuring interaction effects: Results from a Monte Carlo simulation study and voice mail emotion/adoption study. Information Systems Research, 14(2), 189-217.

Cowles, M., \& Davis, C. (1982). On the origins of the .05 level of statistical significance. American Psychologist, 37(5), 553-558.

Craighead, C. W., Patterson, J. W., Roth, P. L., \& Segars, A. H. (2006). Enabling the benefits of supply chain management systems: An empirical study of electronic data interchange (EDI) in manufacturing. International Journal of Production Research, 14(1), 135-157.

DelGaudio, J. (2004). Cygnus interactive, a division of cygnus business media, cross-border trade: Keeping on top of customs regulations. Printed three pages from the internet.

Dillion, W. R., \& Goldstein, M. (1984). Multivariate analysis: Methods and applications. New York: Wiley.

Doug, T., \& Singh, M. (2001). An e-procurement model for B2B exchanges and the role of e-markets. $6^{\text {th }}$ Annual Collector Conference on Electronic Commerce. Coffs Harbour, Pacific Bay Resort.

Fornell, C., \& Larcker, D. (1981). Evaluating structural equitation models with unobservable variables and measurement errors. Journal of Marketing Research, 18(1), 39-50.

Gefen, D., \& Straub, D. (2005, January). A practical guide to factorial validity using PLS-Graph: Tutorial and annotated example. Communications of the Association for Information Systems, 16(1), 91-109.

George, D., \& Mallery, P. (2003). SPSS for Windows step by step: A simple guide and reference 11.0 update (4th $\mathrm{ed}$.$) . Boston: Allyn \& Bacon.$

Glaser, B. G., \& Strauss, A. L. (1967). The discovery of grounded theory: Strategies for qualitative research. Chicago: Transaction Publishers.

Haenlein, M., \& Kaplan, A. M. (2004). A beginner's guide to partial least squares analysis. Understanding Statistics, 3(4), 283-297.

Hair, J.F., Sarstedt, M., Ringle, C.M., \& Mena, J. A. (2012). An assessment of the use of partial least squares structural equation modeling in marketing research. Journal of the Academy of Marketing Science, 40(3), 414-433.

Hennig-Thurau, T., Henning, V., \& Sattler, H. (2007). Consumer file sharing of motion pictures. Journal of Marketing, 71(4), 1-18.

Henseler, J., \& Sarstedt, M. (2013). Goodness-of-fit indices for partial least squares path modeling. Computational Statistics, 28(2), 565-580.

Hesterberg, T., Moore, D. S., Monaghan, S., Clipson, A., \& Epstein, R. (2003). Bootstrap methods and permutation tests. Chapter 14 in Moore, D. S. \& McCabe, G. P. Introduction to the practice of statistics, (5 $5^{\text {th }}$ ed.). [Online]. Retrieved April 19, 2014 from http://bcs.whfreeman.com/pbs/cat_160/PBS18.pdf.

Hsiao, R., \& Teo, T. S. H. (2005). Delivering on the promise of e-procurement. MISQ Executive, 4(3), 343-360.

IE Singapore launches biomedical $\mathrm{R} \& D$ consortium. (2011). [Online]. Government of Singapore, IE Singapore website. Retrieved April 19, 2014, from http://www.news.gov.sg/public/sgpc/en/media_releases/agencies/ie $\% 20$ singa pore/press_release/P-20110623-1/AttachmentPar/0/file/MR02011Biomed\% 20Consortium_2011\%2006\%2023.pdf. 
Kilpatrick, J. (2001). The supply chain e-business top 100 buy: Moving from indirect to direct procurement. SupplyChainBrain.com website. Retrieved April 19, 2014, from www.supplychainbrain.com/archives/6.01Buy100.htm?adcode $=15$.

Kline, P. (2000). The handbook of psychological testing. (2nd ed.) London: Routledge.

Kulp, S. L., Randall, T., Brandyberry, G., \& Potts, K. (2006). Using organizational control mechanisms to enhance procurement efficiency: How GlaxoSmithKline improved the effectiveness of e-procurement. Interfaces, 36(3), 209-219.

Leonard, L. N. K., \& Davis, C. C. (2006). Supply chain replenishment: Before-and-after EDI implementation. Supply Chain Management, 11(3), 225-232.

Mahalik, D. K. (2012). Measuring the effectiveness of e-procurement: A case discussion on MCL. The IUP Journal of Supply Chain Management, 9(2), 19-30.

Manski, C. F. (1996). An introduction to the bootstrap. Journal of Economic Literature, 34(3), 1340-1342.

Mooney, C. Z., \& Duval, R. D. (1993). Bootstrapping: A nonparametric approach to statistical inference. Newbury Park, CA: Sage University Paper series on Quantitative Applications in the Social Sciences.

Moore, J. (2007). E-procurement pays its own way: Strategic sourcing and eProcurement transform purchasing in DeKalb county, GA. [Online]. FCW.COM website. Retrieved April 19, 2014, from http://fcw.com/ articles/2007/04/02/eprocurement-pays-its-ownway.aspx.

Neyman, J., \& Pearson, E. S. (1933, October). The testing of statistical hypotheses in relation to probabilities a priori. Mathematical Proceedings of the Cambridge Philosophical Society, 29(4), 492-510.

Nunnally, J. C. (1978). Psychometric theory (2nd ed.). New York: McGraw-Hill.

Ong, S. H., \& Mei, Q. (2012). Purchasing consortium for the BMS industry in Singapore. Unpublished internal document, National University of Singapore.

Panda, P., \& Sahu, G. P. (2011, June). E-procurement implementation: Comparative study of governments of Andhra Pradesh and Chhattisgarh. The IUP Journal of Supply Chain Management, 8(2), 34-67.

Pupik, J. O. (2014). Explanation: Electronic data interchange standards. [Online]. Retrieved April 22, 2014, from http://www.sis.pitt.edu/ mbsclass/standards/pupik/ edidef.html.

Rajkumar, T. M. (2001). E-procurement: Business and technical issues. Information Systems Management, 18(4), 52-60.

Rasheed, H. S. (2004). Capital access barriers to public procurement: Creating value added in the supply chain. Industrial Marketing Management, 32(3), 219-226.

Ringle, C. M., Wende, S., \& Will, A. (2005). SmartPLS 2.0 (M3) beta. [Online]. University of Hamburg. Retrieved April 22, 2014, from www.smartpls.de.

Rosenbaum, D. (2012). Reining in the spend. CFO, 28(7), 24-25.

Roth, R. T. (2001). Eprocurement: Cutting costs, adding value. Financial Executive, 17(7), 62-63.

Scenario planning in life sciences R \& D. (2009). [Online]. Deloitte's website. Retrieved April 19, 2014, from http://www.deloitte.com/assets/Dcom-UnitedStates/ Local\%20Assets/Documents/us_lshc_ScenarioPlanning_100909.pdf.

Scheel, O., O'Keefe, J., \& Wintermantel, T. (2013). Unleashing pharma from the R\&D value chain. A. T. Kearney, Inc. Retrieved April 19, 2014, from http://www.atkearney.com/paper/-/asset_publisher/dVxv4Hz2h8bS/content/ unleashing-pharma-from-the-r-d-value-chain/10192. 
Straub, D., Boudreau, M. C., \& Gefen, D. (2004). Validation guidelines for IS positivist research. Communications of the Association for Information Systems, 14, 380-426.

Tai, Y. M., Ho, C. F., \& Wu, W. H. (2010). The performance impact of implementing web-based e-procurement systems. International Journal of Production Research, 48(18), 5397-5414.

Waltner, C. (1997). EDI travels the web - EDI over the web offers companies cheaper e-commerce and messaging via browsers. Internetweek, 668.

Waugh, R. (2011). Removing the obstacles to e-procurement adoption. Government Procurement, 19(4), 18-21.

Weitzel, T., Buxmann, P., \& Von Westarp, F. (2000, January). A communication architecture for the digital economy $21^{\text {st }}$ century EDI (pp. 10). Proceedings of the 33rd Annual Hawaii International Conference on System Sciences. IEEE.

Wening, A., \& Brockmann, P. (2001). Electronic procurement: Concepts, instruments and benefits. Nurnberg, Germany: Georg-Simon-Ohm Fachhochschule.

Wetzels, M., Odekerken-Schröder, G., \& van Oppen, C. (2009). Using PLS path modeling for assessing hierarchical construct models: Guidelines and empirical illustration. MIS Quarterly, 33(1), 177-195.

Wong, K. K. (2011, January). Book review: Handbook of partial least squares: Concepts, methods and applications. In V. Esposito Vinzi, W.W. Chin, J. Henseler \& H. Hwang (Eds.). International Journal of Business Science \& Applied Management, 6(2), 52-54.

Yen, B. P., \& Ng, E. (2003). The impact of electronic commerce on procurement. Journal of Organisational Computing \& Electronic Commerce, 13(3-4), 167-189. 